\title{
O conceito de Imperialismo para Caio Prado Jr
}

\author{
Marília Thomaz da Silva (IC)
}

\section{Resumo}

O objetivo desta pesquisa foi analisar o conceito de imperialismo dentro da obra de Caio Prado $\mathrm{Jr}$ e a importância dos fluxos de exportação de capital vindos para o Brasil na fase de capitalismo monopolista a partir de três eixos temáticos: 1) formação do conceito de Imperialismo para o autor; 2) Imperialismo e herança colonial brasileira; 3) crítica de Caio Prado Jr aos teóricos do Partido Comunista Brasileiro.

Palavras Chave: Caio Prado Jr, Imperialismo, economia brasileira

\section{Introdução}

Dentro da obra de Caio Prado Jr, o objetivo desta pesquisa foi compreender o conceito de Imperialismo e a importância dos fluxos de exportação de capital vindos para o Brasil na fase de capitalismo monopolista. Para tanto, foram elencados três eixos temáticos: 1)-Conceito de Imperialismo de Caio Prado Jr a partir do debate clássico. Em tal tópico tratamos as seguintes questões: a)- Como Caio Prado Jr formou seu conceito de Imperialismo; b)- Quais autores potencialmente influenciaram Caio Prado Jr. 2)Imperialismo e herança colonial brasileira. Aqui, nossa preocupação foi analisar três características deste tema: a)- Qual a especificidade histórica de um país de herança colonial como o Brasil; b)- Quais os impactos do imperialismo em uma economia periférica com este estilo de formação capitalista; c)- De que forma a ação imperialista sobre o Brasil bloqueou a possibilidade de superação da herança colonial. 3)- Crítica de Caio Prado Jr aos teóricos do PCB (Partido Comunista Brasileiro). Nosso desafio neste tópico foi compreender como Caio Prado Jr rompeu com a tradição marxista brasileira ao fixar-se na investigação das particularidades históricas brasileiras sem enquadrá-las em esquemas teóricos pré-estabelecidos. Para chegar a tal objetivo foram realizadas leituras das principais obras do autor (História Econômica Geral, A Revolução Brasileira, Esboço sobre os Fundamentos da Teoria Econômica e História e Desenvolvimento), além de pesquisarmos em autores clássicos que trataram do tema do Imperialismo, como Vladimir Lênin e Nicolai Bukharin.

\section{Resultados e Discussão}

Nesta pesquisa procuramos ressaltar a análise que Caio Prado Jr fez da exportação de capital dos países centrais para aqueles países periféricos que tem uma herança colonial, como 0 Brasil. O autor fez um exame aprofundado tanto das condições que incentivaram o primeiro grupo de países a exportar, como dos impactos que estas exportações tiveram no segundo grupo. No caso dos países centrais o autor fez seu estudo pela ótica da valorização de capital, o que o aproxima dos autores de tradição marxista, dentro do debate clássico sobre o Imperialismo. A inovação de seu pensamento acontece na sua investigação dos impactos da exportação de capital em países de origem colonial, ao fazer esta análise a partir da especificidade de um país de origem colonial. Detalhes relevantes da metodologia podem ser descritos neste item.

\section{Conclusões}

Esta pesquisa demonstra a grande relevância de Caio Prado Jr, não apenas dentro da tradição marxista, mas dentre todos os pensadores que estudaram o Brasil, ao analisar as especificidades de um país de origem colonial.

\section{Agradecimentos}

Esta pesquisa foi financiada pela PIBICUNICAMP, programa da CNPQ, a qual gostaria de agradecer. 